\title{
Chapter 4 \\ Reproduce to Understand: Experimental Approach Based on Footprints in Cussac Cave (Southwestern France)
}

\author{
Lysianna Ledoux, Gilles Berillon, Nathalie Fourment, and Jacques Jaubert
}

\begin{abstract}
The morphology of a track depends on many factors that must be considered when interpreting it. An experimental approach is often required to understand the influence of each of these factors, both at the time of the track formation and after its formation. These aspects, which are fairly well documented for tracks found in open-air settings, are much more limited for those found in karst settings. Although caves are stable environments enabling the preservation of archaeological remains, many taphonomical processes can alter the grounds and the walls. Based on the observations made on footprints found in Cussac Cave (Dordogne region of southwestern France), this study focuses on one of these natural phenomena and tests the impact of flooding episodes and the resulting clay deposits on the track's morphology and topography. Our experiments show that although the general morphology of footprints and some details such as digits are preserved, their topography is altered by successive flooding episodes and clay deposits. The loss of definition of the footprints due to flooding episodes can also lead to misinterpretation. This work sheds new light on the Cussac footprints, while the further development of such experiments will allow us to improve our results and apply them to other settings and sites.
\end{abstract}

Keywords Taphonomy $\cdot$ Footprint $\cdot$ Cave $\cdot$ Palaeolithic $\cdot$ Experimentation

\author{
L. Ledoux $(\bowtie) \cdot$ J. Jaubert \\ Université de Bordeaux, Pessac, France \\ e-mail: ledouxlysianna@gmail.com \\ G. Berillon \\ UMR7194 MNHN-CNRS/Département Homme et Environnement, Musée de l'Homme, Palais \\ de Chaillot, Paris, France \\ N. Fourment \\ SRA, DRAC Nouvelle Aquitaine 54 rue Magendie, Bordeaux Cedex, France
}

(C) The Author(s) 2021

A. Pastoors, T. Lenssen-Erz (eds.), Reading Prehistoric Human Tracks, https://doi.org/10.1007/978-3-030-60406-6_4 


\section{Introduction}

Tracks are among the most fragile and underestimated of archaeological remains, yet they provide a valuable source of information on site frequentation. They are the direct representation of a particular event in an individual's life, the marker and proof of human or non-human passage through a place. They offer an essential insight into the biology, locomotion, behaviour or activities of trackmakers. In the absence of other remains, tracks may even be the only elements enabling an exploration of the frequentation of a site.

Over the last few decades, and recently, palaeoichnological studies have been regularly conducted in open-air settings and have benefited from the development of new recording and analysis techniques (Mietto et al. 2003; Berge et al. 2006; Webb et al. 2006; Aramayo 2009; Bennett et al. 2009; Raichlen et al. 2010; Felstead et al. 2014; Ashton et al. 2014; Burns 2014; Bennett et al. 2016; Masao et al. 2016; Panerello et al. 2017; Wiseman and De Groote 2018; Altamura et al. 2018; McLaren et al. 2018; Smith et al. 2019; Moreno et al. 2019). In cave settings, they reached their peak between the 1970s and the early 2000s but were less developed (Duday and Garcia 1985, 1986; Garcia 1986). Human and non-human tracks have been documented and studied in the caves of Niaux (Clottes and Simonnet 1972; Pales 1976; Garcia et al. 1990), Pech Merle (Duday and Garcia 1983), Foissac (Garcia and Duday 1983), Aldène (Ambert et al. 2000; Ambert et al. 2001) and Chauvet Pont d'Arc (Garcia 2001, 2005). Recently, interest in ichnology in the karst setting has re-emerged among prehistorians, who have resumed the study of tracks in several ornated caves such as the Tuc d'Audoubert (Bégouën et al. 2009; Pastoors et al. 2015; see Pastoors et al. Chap. 13), Pech Merle (Pastoors et al. 2017), Aldène (Pastoors et al. 2015; see Galant et al. Chap. 15), Cussac (Ledoux et al. 2017; Ledoux 2019), Fontanet (Pastoors et al. 2015; Ledoux 2019), Bàsura (Citton et al. 2017; Romano et al. 2019; see Avanzini et al. Chap. 14) and Ojo Guareña (Ortega Martinez et al. 2014; see Ortega et al. Chap. 17).

Given the variety of factors that are likely to have impacted the morphology of hominin tracks (from the biology of the trackmakers to the nature of the substrate and taphonomic agents), experimental approaches have been developed, especially over the last decade, inspired by the work done on non-hominin tracks (Sollas 1879; Brand 1996; Gatesy 2003; Milàn and Bromley 2007).

The first studies were those conducted by Léon Pales, who observed variations in the footprints of the same trackmaker according to the sediment and the foot dynamic (Pales 1976). These works related to karst were pioneering and have no equivalent in this type of setting. Subsequent experiments focused on the footprints of early hominins in open-air settings and were developed within comparative and functional perspectives. Since the year 2000, an increasing number of experimental works have been conducted in response to the development of new tools (pressure pad for the recording of plantar pressure and 3D surface recording techniques such photogrammetry or optical laser scanning). The properties of the formation sediment are also central (Pataky et al. 2008a; Pataky and Goulermas 2008; Pataky et al. 
2008b; D'Août et al. 2010; Crompton et al. 2012; Bennett et al. 2013; Morse et al. 2013; Hatala et al. 2013; Bennett and Morse 2014; Hatala et al. 2018; Zimmer et al. 2018). However, the potential impact of taphonomical agents remains poorly investigated and has been examined in open-air settings (Marty et al. 2009; D'Août et al. 2010; Bennett and Morse 2014; Roach et al. 2016; Panerello et al. 2017; Hatala et al. 2018; Wiseman and De Groote 2018).

Although varied in their objectives and contexts, these studies demonstrate that our interpretations of tracks require a better understanding of both the formation and the conservation setting. Each track is unique, and the objective of the ichnological study is to understand the factors behind this uniqueness. Despite increasing interest in the study of tracks in caves (Ortega Martinez et al. 2014; Pastoors et al. 2015; Pastoors et al. 2017; Citton et al. 2017; Ledoux 2019; Romano et al. 2019), ichnology in Palaeolithic caves is still little known and the formation and conservation context of these caves poorly studied. Here we present our first results drawn from experiments focusing on the impact of flooding on human footprints. This natural phenomenon has been observed in Cussac Cave (Ledoux 2019) and is recurrent in the cave setting.

\section{The Karst Setting}

\section{Formation}

As with the open-air setting, the morphology of a track produced in cave depends on the sediment and the trackmaker. Tracks are the result of the compression of sediment in response to a constraint exerted by a trackmaker; the original morphology of tracks therefore depends on both the trackmaker (locomotion, biology, behaviour, etc.) and the formation sediment (physical and mechanical properties, topography, etc.). Over time, this original morphology will be influenced by various taphonomic phenomena (erosion, bioturbation, filling, etc.). The interpretation of tracks must therefore be based first and foremost on a knowledge and understanding of their setting.

However, a third parameter can influence this morphology: the geomorphology of the karst. The movements and behaviour of trackmakers will then be highly dependent on the topography of the ground and the morphology of the walls, the height of the ceilings and the width of the network. Consequently, the resulting tracks will have a particular morphology whose interpretation will also depend on how well the trackmaker's perception of the cave is understood.

While tracks found in open-air settings generally belong to trackways, those found in caves are much more varied. Testimonies of intentional or non-intentional actions, these tracks are characterized by complete (foot, hand, knee, etc.) or partial (fingers, toes, heels, etc.) body segments. Often associated with wall traces (torch, colour or clay marks), they are the result of a variety of behaviours that are influenced either by the geometry of the cavity or by the activities 
that took place inside them (Bégouën et al. 2009; Pastoors and Weniger 2011; Arias et al. 2011; Ledoux et al. 2017; Medina-Alcaide et al. 2018; Romano et al. 2019).

The surface soils of a cave may have different characteristics depending on the area (various clastic sediment deposits with different sedimentary properties, calcite deposits, etc.). It may therefore be difficult to attribute several tracks to a single trackmaker if they are not produced in the same area, especially where isolated tracks are concerned.

\section{Preservation Context}

The stability of caves makes them ideal environments for the preservation of the most fragile archaeological remains, as is very well reflected in rock art. However, despite their exceptional conservative properties, caves may be subjected to taphonomical processes during their lifetime. These phenomena are varied and are generally classified into two categories (Fig. 4.1):

- Natural phenomena including sediment fillings (various sedimentary deposits), flooding, calcite deposits, erosion, desiccation, etc.

- Non-natural phenomena including trampling, track superimpositions, excavation, etc.

The same track may have been altered by one or more of these taphonomic processes. Therefore, the karst setting must be understood before the tracks can be interpreted.

\section{Cussac Cave}

\section{Contextual Setting}

Discovered in 2000 by the speleologist Marc Delluc, Cussac Cave is located south of Périgord in Dordogne (southwestern France). It opens onto a Campanian limestone cliff on the right bank of the Belingou, a tributary of the Dordogne River. It extends along some $1.6 \mathrm{~km}$ in a single sub-horizontal gallery divided into two parts: the Downstream Branch and the Upstream Branch (Fig. 4.2). This particularly wellpreserved cave is characterized by parietal engravings and human remains deposited in bear hibernation nests, both associated with varied traces of human and non-human activity (Aujoulat et al. 2001, 2002, 2013; Fourment et al. 2012; Jaubert et al. 2012; Henry-Gambier et al. 2013; Jaubert 2015; Ledoux et al. 2017). All archaeological remains (art, charcoal, human bones) are attributed to human occupation in the Middle Gravettian period (20-28 ka calBP) (Jaubert et al. 2017). Since 2008, a multidisciplinary team has been studying the cave in order to gain a global understanding of the site. During the first few years of research, a pathway was 

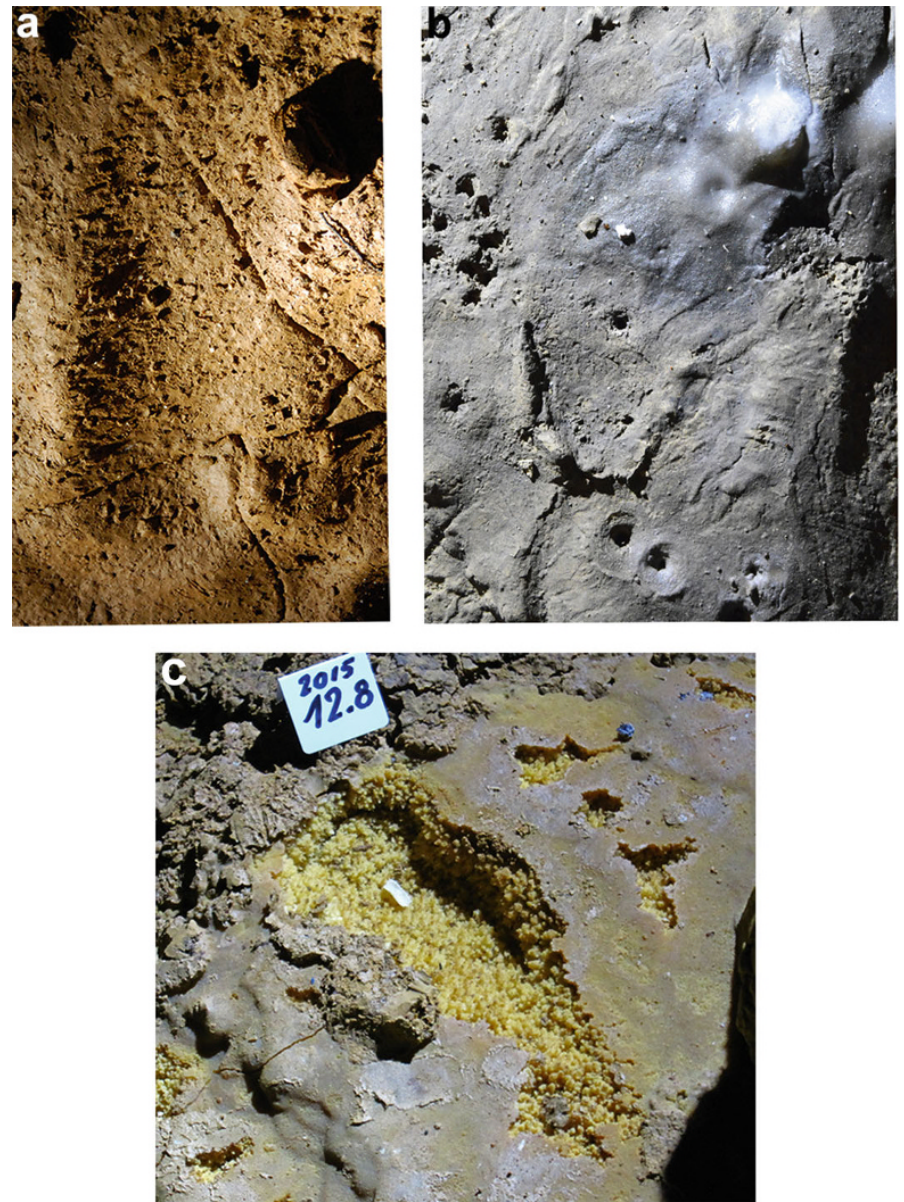

Fig. 4.1 Examples of taphonomical processes occurring in karst settings; (a) human footprint covered by clay deposits in Cussac Cave (Dordogne, France); (b) human footprint covered by concretion in Fontanet Cave (Ariège, France) (Ledoux et al. 2017); (c) bear manus track transformed into rimstone in Bruniquel Cave (Tarn-et-Garonne, France)

marked throughout the cave, following the one first taken by the discoverer. The aim of maintaining this single pathway is to ensure optimum preservation of the cave floors and walls.

\section{Tracks at Cussac and Taphonomy}

Although the cave is very well preserved, the current floors are not exactly the same as they were in the Palaeolithic. Consequently, few tracks have been clearly 
a
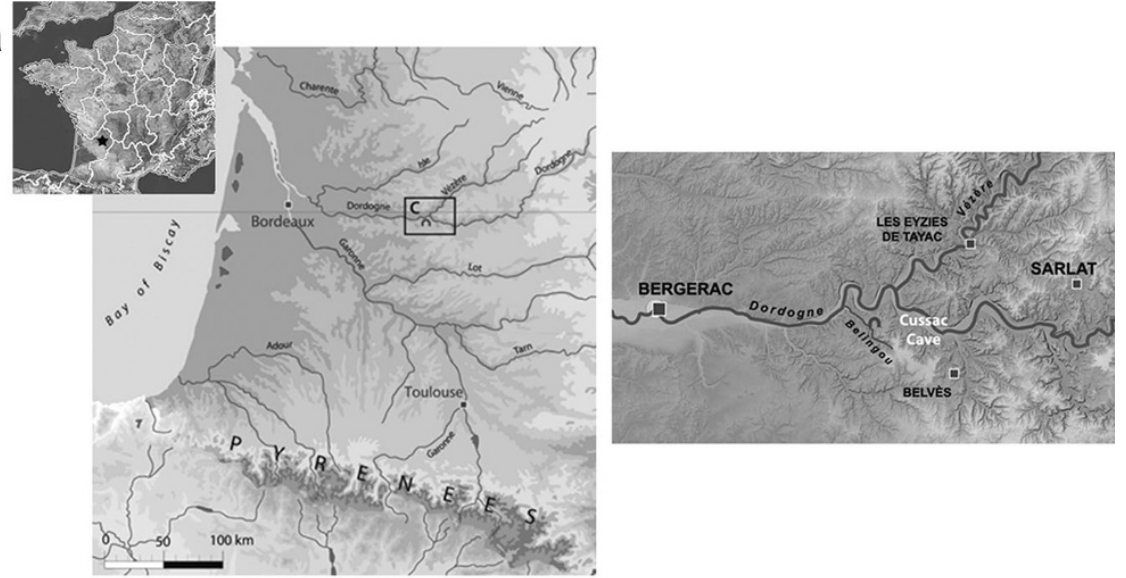

b
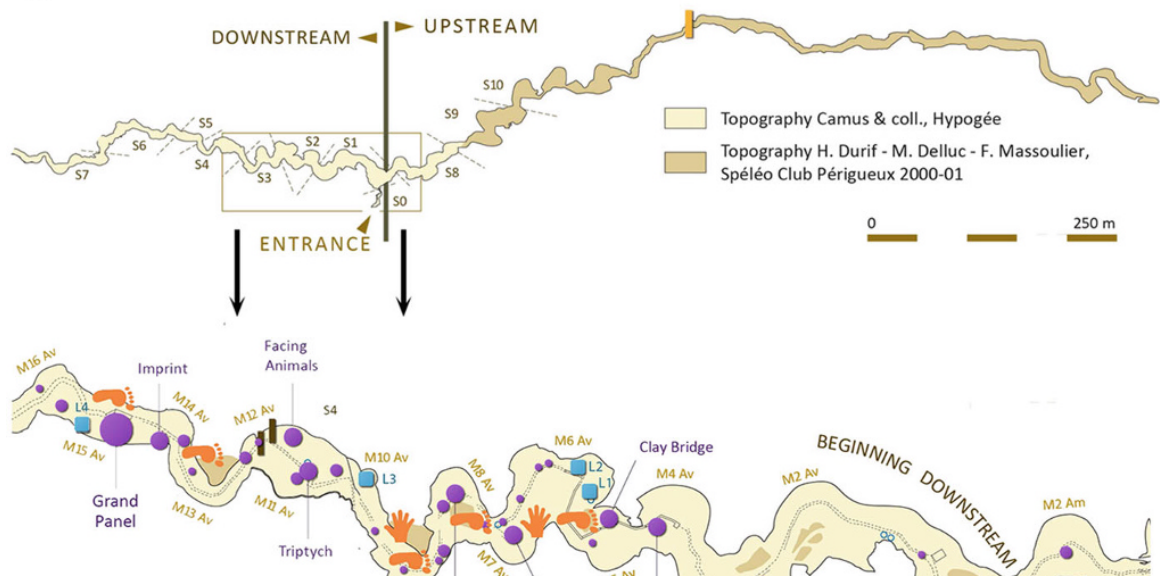

ARCHEOLOGY

$\underset{\substack{\text { RUMMAN } \\ \text { REMAINS Locus }} \text { locus to be confirmed }}{\operatorname{Ar}}$

ARTEFACTS Reindeer antler

I Soint

PARIETAL ART $10 \begin{aligned} & \text { Main panel } \\ & \text { Other panel, } \\ & \text { isolated graphic entity }\end{aligned}$

1 blade

TRACSS I"' Handprints

$\bigcirc$ Footprints

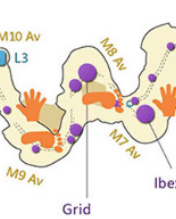

Grid

Ibex

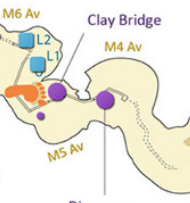

Discovery

LAYOUTS

= walkways

Progression paths

KARST

Pilar
and/or

Collapsed block

- well

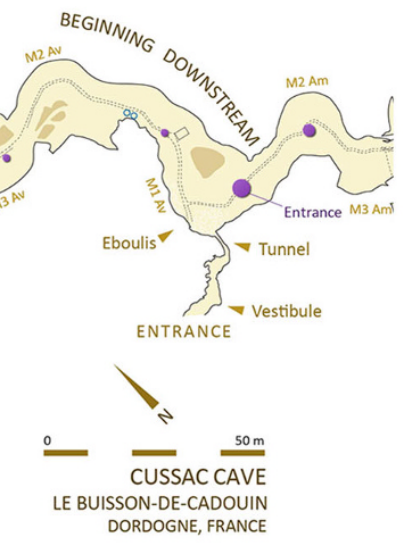

(P) sac

Fig. 4.2 (a) Geographic location of Cussac Cave; (b) general topography of Cussac Cave and close up of the part of the cave under study 
identified as human tracks. Several factors may explain this poor preservation of the Palaeolithic cave floors (Ledoux et al. 2017; Ledoux 2019):

- Geological factors: after human occupation, the cave underwent various sedimentary events which significantly damaged the floors (sedimentary deposits, erosion, flooding, desiccation cracks, etc.).

- The omnipresence of bears in the cave. Bear tracks and human tracks are superimposed in several areas.

- The restricted accessibility of some areas due to the conservation policy.

- The current pathway which is, in some areas, probably the same as the Palaeolithic pathway.

As a consequence of these various taphonomical processes, most of the complete footprints are isolated and often altered (Fig. 4.2). Below we present the experiment carried out on the basis of one of these taphonomical phenomena, frequently observed in caves: the overflow of the subterranean river. In some areas of Cussac Cave, several flooding episodes occurred after human frequentation, covering tracks with clay (Fig. 4.1a). Through a controlled experiment, we intend to test the impact of clay deposits on the morphology and topography of footprints after flooding episodes. Assuming that water and sediment affect the contours and the general surface of the footprints, our purpose is therefore to follow the evolution of a footprint from immediately after its formation to its covering by clay deposits.

\section{Materiel and Methods}

\section{Experimental Protocol}

Experimental footprints were made in a cohesive, firm and moist sediment that we selected for its high clay content, similar to that of Cussac. It allowed for the impression of an entire foot. This sediment was sampled from a cave in the Dordogne region of southwestern France without any archaeological remains (Table 4.1).

From this sediment, two types of formation surface were used: one of raw clay with a moisture content of about $50 \%$ and one of raw clay covered with a second level of clay that had settled after flooding (called the first decantation) (Fig. 4.3) and

Table 4.1 Grain size analyses of the sediment sampled in Cussac Cave and in the experimental cave

\begin{tabular}{l|l|l|l|l}
\hline Samples & $\begin{array}{l}\text { Fine sand }(\%) \\
(500-63 \mu)\end{array}$ & $\begin{array}{l}\text { Coarse silt }(\%) \\
(63-16 \mu)\end{array}$ & $\begin{array}{l}\text { Fine silt }(\%) \\
(16-7 \mu)\end{array}$ & $\begin{array}{l}\text { Clay }(\%) \\
(<7 \mu)\end{array}$ \\
\hline Cussac & 2.56 & 18.99 & 22.59 & 55.85 \\
\hline $\begin{array}{l}\text { Experimental } \\
\text { cave }\end{array}$ & 2.8 & 10.78 & 30.42 & 56 \\
\hline
\end{tabular}


Fig. 4.3 Experimental steps

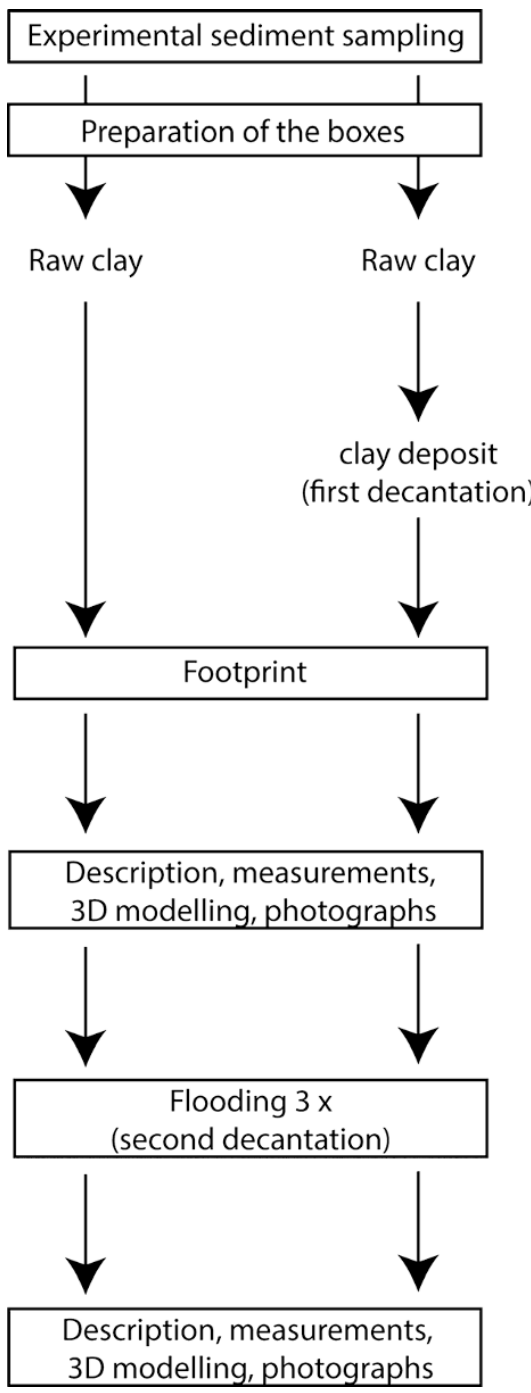

with a moisture content varying between $60 \%$ and $70 \%$ (Fig. 4.3). Before creating the second substrate, we tested the impact of different sediment loads ( $60 \mathrm{~g} / \mathrm{l}, 80 \mathrm{~g} / \mathrm{l}$ and $100 \mathrm{~g} / \mathrm{l})$ from the first decantation on the morphology of the tracks.

Experimental footprints were made by two people: a female individual with a height of $1.69 \mathrm{~m}$, weighing $55 \mathrm{~kg}$ and with a foot length of $24 \mathrm{~cm}$, and a male individual with a height of $1.80 \mathrm{~m}$, weighing $75 \mathrm{~kg}$ and with a foot length of $24 \mathrm{~cm}$. The footprints were made in boxes of identical dimensions: $50 \times 40 \times 25 \mathrm{~cm}$.

The second step consisted in covering the footprints with water $(1.5$ 1) that contained a defined sediment load (called the second decantation). Based on the scenario that the cave suffered several low-power floods, the first substrates of three 
sediment loads were arbitrarily selected and tested ( $20 \mathrm{~g} / \mathrm{l}, 40 \mathrm{~g} / \mathrm{l}$ and $60 \mathrm{~g} / \mathrm{l})$ to see whether there were any noticeable differences after the last flooding episode. As the second substrate was less cohesive and less stable, it was more difficult to control for its properties. We therefore chose to keep the three sediment loads in order to understand more broadly the variability of the footprints in this type of sediment.

A maximum of three flooding episodes were carried out for each footprint.

Finally, out of a total of 19 footprints, 8 were selected for the comparative analysis. The remaining 11 are the tracks made when our experimental protocol was established.

During the decantation process, the footprints were kept in a relatively stable environment $\left(21^{\circ} \mathrm{C}\right.$ and $50-85 \%$ humidity according to the weather conditions outside). The aim was to avoid excessively rapid drying and potential desiccation cracks.

\section{Descriptions, Metrics and 3D Models}

After each step, the footprints were described in detail, distinguishing two aspects: the general morphology, which concerns the shape and the outline of the footprint, and its topography, related to its elevation and the state of its surface. In addition, seven measurements considered as most indicative of the print morphology were recorded: length 1 (distance between the most distal point of the hallux and the most inferior point of the pternion), length 2 (distance between the most distal point of the second toe and the most inferior point of the pternion), length 3 (distance between the most distal point of the forefoot and the most inferior point of the pternion), digits width (distance between the most medial point of the hallux and the most lateral point of the last toe), distal width (distance between the most medial point and the most lateral point of the forefoot), middle width (distance between the most medial point and the most lateral point of the longitudinal arch) and proximal width (distance between the most medial point and the most lateral point of the heel). They were photographed using a Nikon D7100 with a $60 \mathrm{~mm}$ focal length lens. Then each footprint was 3D digitized using an Artec EVA 3D light scanner 2013 (Artec Group, Luxembourg). This scanner uses the structured light triangulation technique to reconstruct a 3D model of the footprint. The accuracy achieved by this scanner is $0.5 \mathrm{~mm}$ at a working distance of $40 \mathrm{~cm}$ to $1 \mathrm{~m}$, and the 3D resolution goes up to $0.1 \mathrm{~mm}$. The scanner takes up to 16 frames per second and transfers them to the Artec Studio software (Modabber et al. 2016) which aligns the frames in real time.

Post-processing was performed on the Artec Studio 9 software, which recreated a colour texturized 3D mesh.

The 3D models of the footprints at different moments of the experiment were visualized and compared with CloudCompare (2.8.1.). We used part of the standard protocol proposed by Falkingham et al. (2018) to record, present and archive our 3D 
data. The true colour image, depth map and contour map (range of $0.5 \mathrm{~mm}$ ) were therefore created for each footprint.

For the comparative analysis, clouds of each footprint were aligned using the CloudCompare Align tool. The multiscale Model to Model Cloud Comparison algorithm (M3C2) (Lague et al. 2013) was then used. It computes the local distance directly between two point clouds along the normal surface direction. For each distance measurement, it calculates a confidence interval based on the point cloud roughness and coregistration error. This computation serves to evaluate morphological 3D changes in surface orientation. These changes are expressed in colourized texture from the reference point cloud.

\section{Results}

\section{Formation Sediment and Flooding Sediment Load}

\section{Formation Sediment}

The tests carried out in order to verify the impact of different sediment loads $(60 \mathrm{~g} / \mathrm{l}$, $80 \mathrm{~g} / \mathrm{l}$ and $100 \mathrm{~g} / \mathrm{l}$ ) from the first decantation on the morphology of the tracks do not show any obvious differences between the footprints made on these three sediment loads. Since the general morphology and topography did not seem to vary, we used the average load of $60 \mathrm{~g} / \mathrm{l}$ for subsequent experiments (Fig. 4.4a).

\section{Flooding Sediment Load}

No obvious differences were identified between the three sediment loads $(20 \mathrm{~g} / \mathrm{l}$, $40 \mathrm{~g} / \mathrm{l}$ and $60 \mathrm{~g} / \mathrm{l}$ ) tested on the footprints made in the first substrate, particularly as regard the loads of $40 \mathrm{~g} / \mathrm{l}$ and $60 \mathrm{~g} / \mathrm{l}$. The average load of $60 \%$ was therefore used for subsequent experiments (Fig. 4.4b).

\section{General Morphology}

The original experimental footprints are well defined and complete, regardless of the formation sediment and the trackmaker. The distal and proximal parts are the deeper ones. Although the middle part is shallower, the medial longitudinal arch is generally well defined. Digit prints are also easily distinguishable throughout our sample (Figs. 4.5a, b, c, 4.6a, b, c).

Experimental flooding affects the footprints' morphology in several ways. The medial part of the footprint is the first to disappear after flooding episodes, irrespective of the formation sediment and the sediment load. After the third 
Fig. 4.4 (a) Footprints made on the second surface, no obvious difference according to the sediment load used; (b) footprints made in raw clay and covered with clay deposit after three flooding episodes, no obvious difference according to the sediment load used

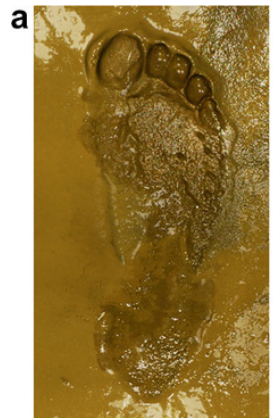

$60 \mathrm{~g} / \mathrm{L}$

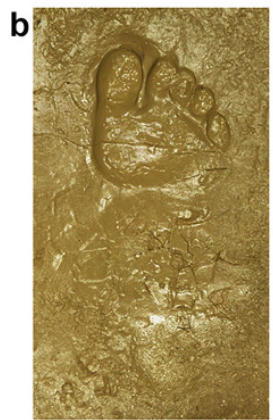

$20 \mathrm{~g} / \mathrm{L}$

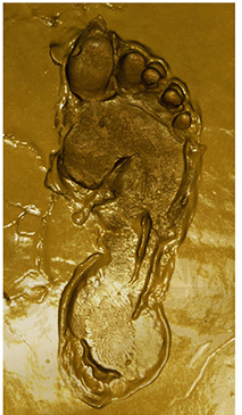

$80 \mathrm{~g} / \mathrm{L}$

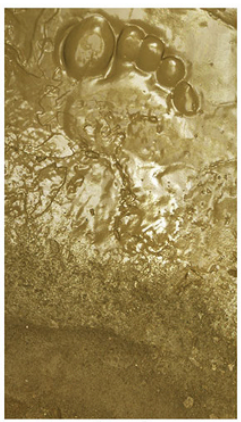

$40 \mathrm{~g} / \mathrm{L}$

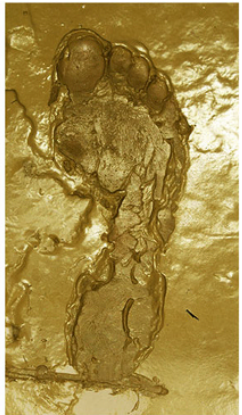

$100 \mathrm{~g} / \mathrm{L}$

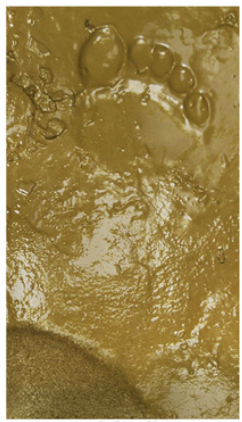

$60 \mathrm{~g} / \mathrm{L}$

$10 \mathrm{~cm}$

flooding, this part is no longer visible on any print. The proximal part of the footprint is the second part to disappear after flooding episodes. After the last flooding, this part remains on two prints only. The distal part is the one that persists the longest throughout the flooding episodes. Five footprints retain their distal part after the last flooding. Within this part, the forefoot tends to be less visible more frequently than the digits. The hallux is the most persistent of the digits (Figs. 4.5d, e, f, 4.6d, e, f).

Generally, the flooding causes a loss of definition of the contours of the prints, which could have distorted the way they were perceived when measurements were taken. However, the many flooding episodes only modify the dimensions of the remaining areas by a few millimetres. For some footprints, the measurements of certain areas were sometimes over- or underestimated (Table 4.2). The footprint made by individual 2 in the second surface, flooded with water loaded with $80 \mathrm{~g} / \mathrm{l}$ of sediment, is very representative, with a length that varies by almost $4 \mathrm{~cm}$ between the original experimental footprint and the remaining part of it after the first flooding (Table 4.2). 

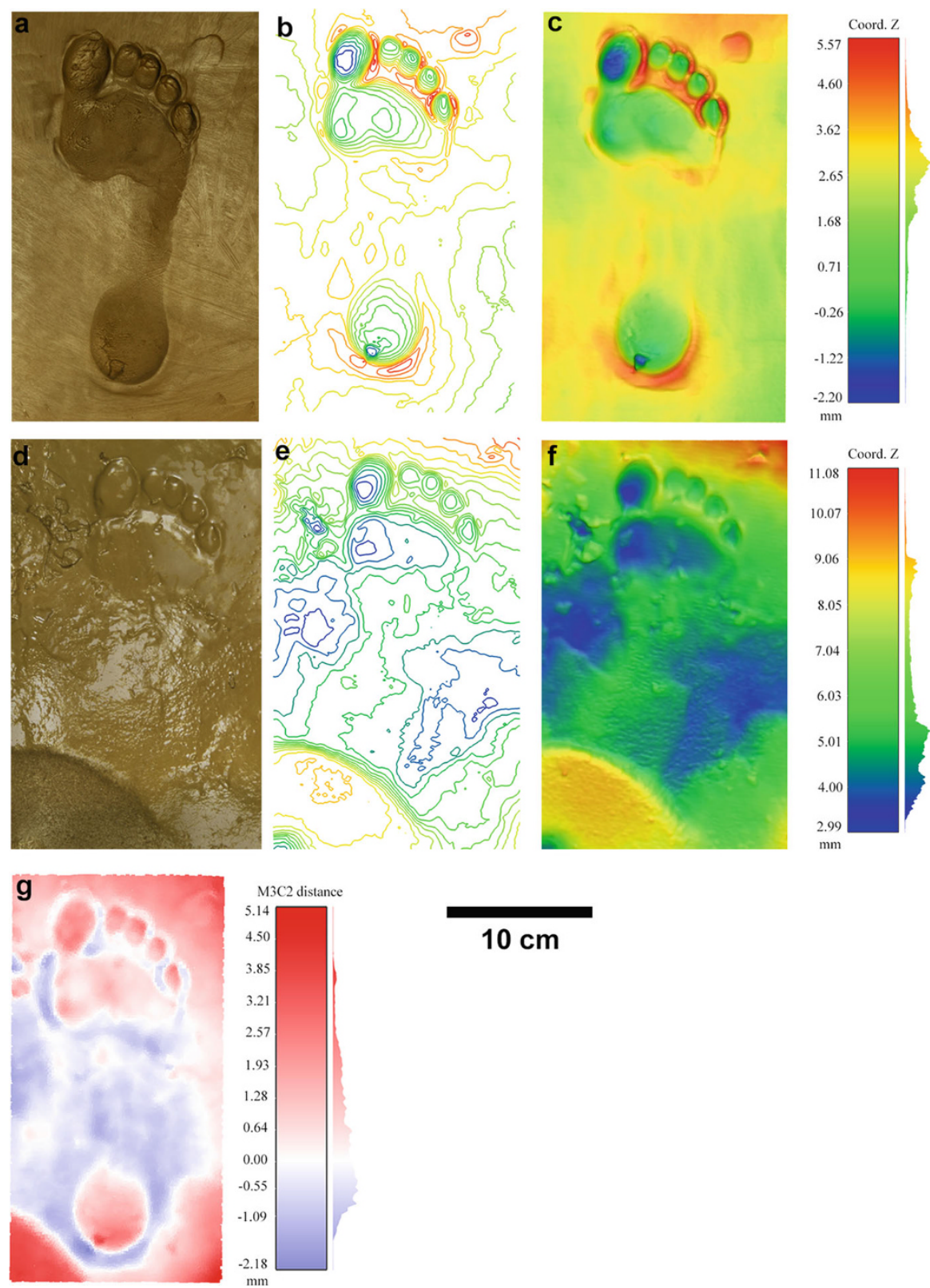

$10 \mathrm{~cm}$

Fig. 4.5 Footprint made in the first surface by individual 1 and flooded with water containing a sediment load of $60 \mathrm{~g} / 1$; (a) first step, true colour image; (b) first step, contour map; (c) first step, depth map; (d) third flooding, true colour image; (e) third flooding, contour map; (f) third flooding, depth map; (g) M3C2 distance between the first step (original footprint) and the last step (after the third flooding) 

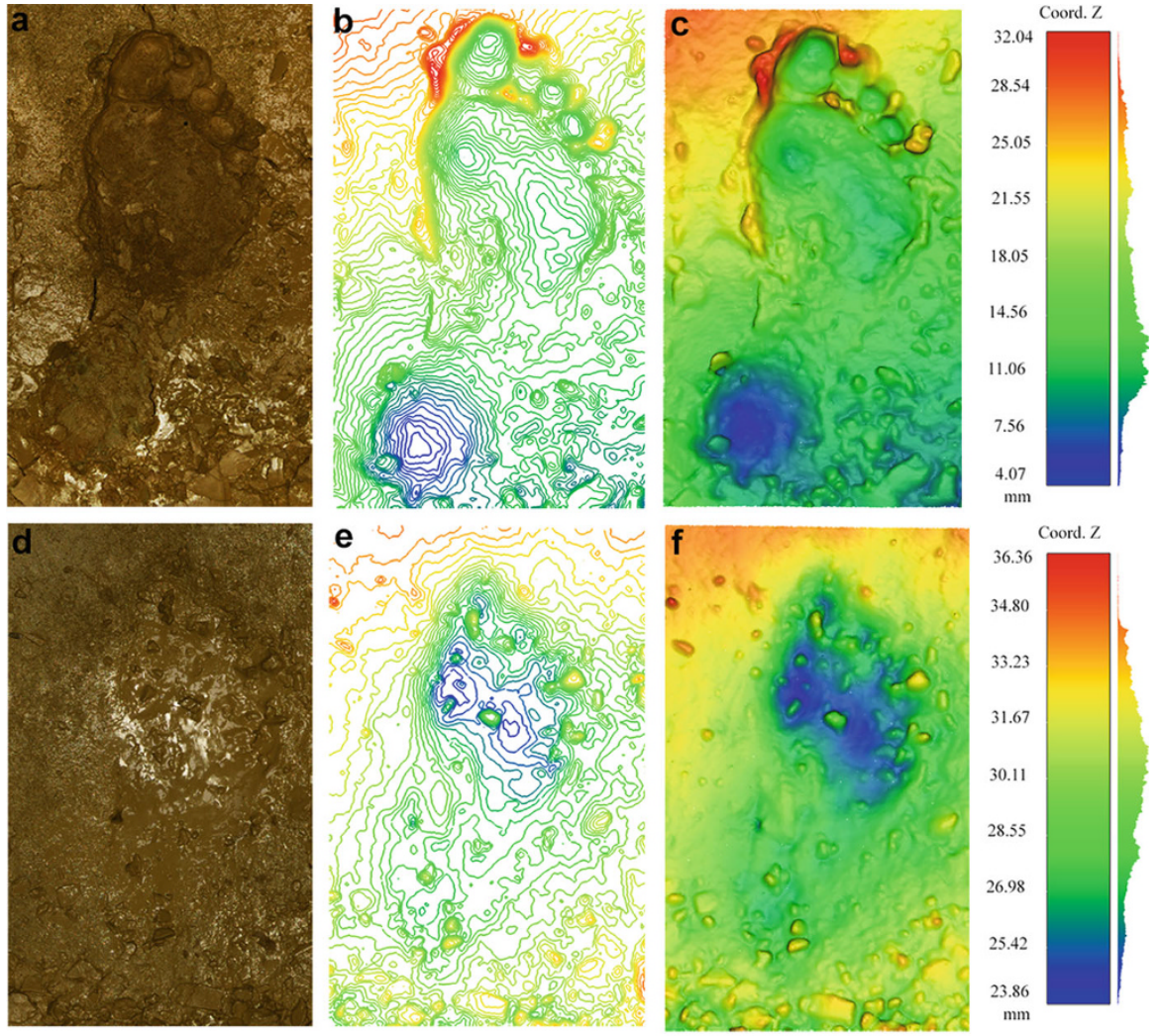

Coord. Z
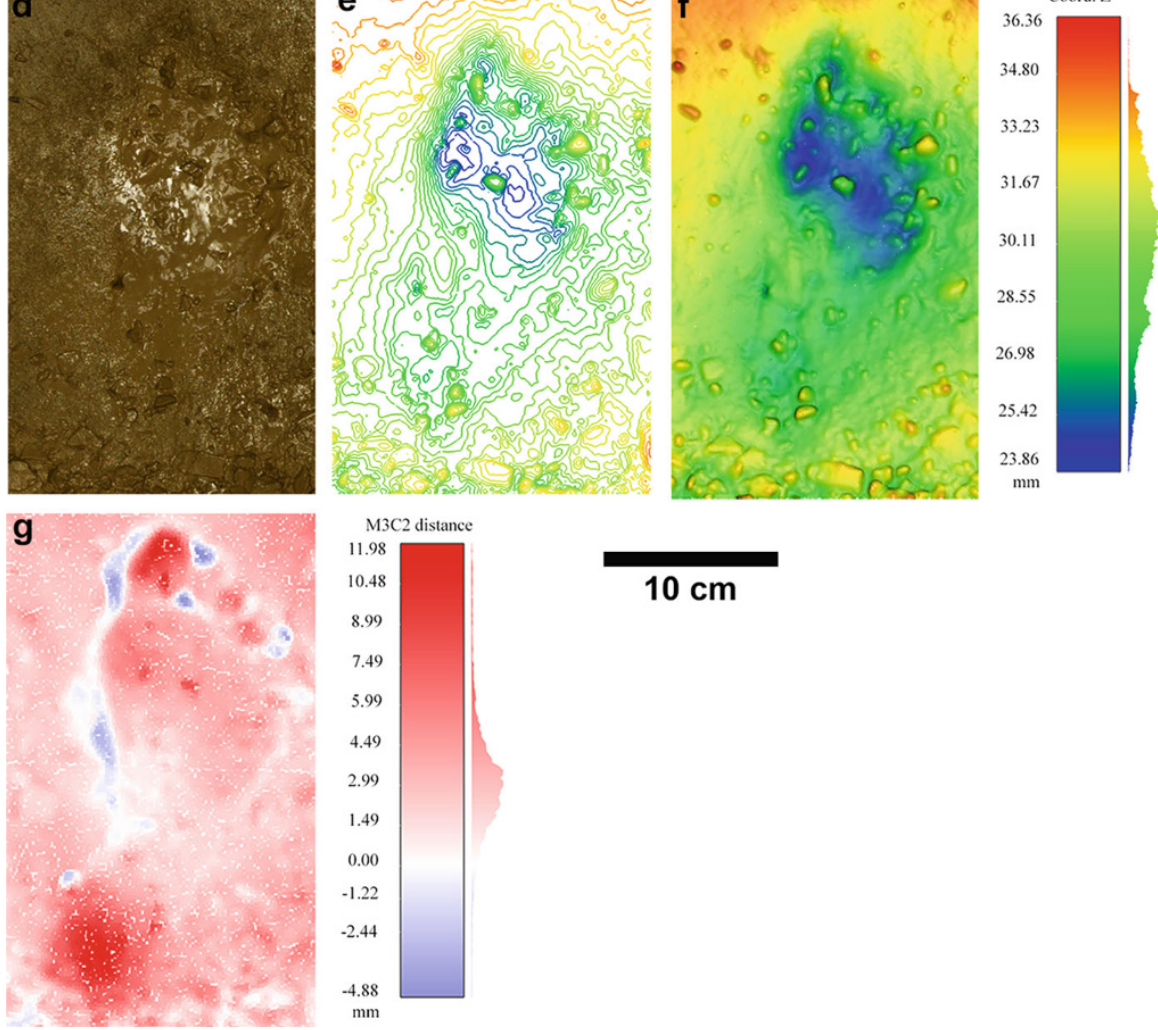

\section{$10 \mathrm{~cm}$}

Fig. 4.6 Footprint made in the second surface by individual 2 and flooded with water containing a sediment load of $60 \mathrm{~g} / \mathrm{l}$; (a) first step, true colour image; (b) first step, contour map; (c) first step, depth map; (d) third flooding, true colour image; (e) third flooding, contour map; (f) third flooding, depth map; (g) M3C2 distance between the first step (original footprint) and the last step (after the third flooding) 
Table 4.2 Biometry of the experimental footprints $(\mathrm{cm})$

\begin{tabular}{|c|c|c|c|c|c|c|c|c|c|c|}
\hline Surface & SL & I & Step & $\begin{array}{l}\text { FL } \\
1\end{array}$ & $\begin{array}{l}\text { FL } \\
2\end{array}$ & $\begin{array}{l}\text { FL } \\
3\end{array}$ & $\begin{array}{l}\text { FW } \\
\text { distal }\end{array}$ & $\begin{array}{l}\mathrm{FW} \\
\text { middle }\end{array}$ & $\begin{array}{l}\text { FW } \\
\text { proximal }\end{array}$ & $\begin{array}{l}\text { FW } \\
\text { digits }\end{array}$ \\
\hline \multirow{7}{*}{$\begin{array}{l}\text { First } \\
\text { surface }\end{array}$} & \multirow[t]{7}{*}{$60 \mathrm{~g} / 1$} & \multirow[t]{4}{*}{1} & 1 & 23.8 & 23 & 19.9 & 8.5 & 3.2 & 5.3 & 9.5 \\
\hline & & & 2 & 23.3 & 22.4 & 19.4 & 8.3 & & 5.3 & 9.6 \\
\hline & & & 3 & 23 & 22.3 & 19.8 & 8.5 & & 5.5 & 9.5 \\
\hline & & & 4 & & & & 8.5 & & & 9.5 \\
\hline & & \multirow[t]{3}{*}{2} & 1 & 24.7 & 24.3 & 20.8 & 10 & & 4.7 & 9.5 \\
\hline & & & 2 & & & & 9.7 & & & 9.5 \\
\hline & & & 3 & & & & 9 & & & 8.5 \\
\hline \multirow{19}{*}{$\begin{array}{l}\text { Second } \\
\text { surface }\end{array}$} & \multirow[t]{8}{*}{$40 \mathrm{~g} / \mathrm{l}$} & \multirow[t]{4}{*}{1} & 1 & 23.7 & 23.5 & 20.4 & 8.5 & 4.2 & 5.3 & 9.0 \\
\hline & & & 2 & 23.4 & 22.4 & 20.7 & 8 & 4.5 & 5.2 & 9.3 \\
\hline & & & 3 & & & & 7 & & & 9 \\
\hline & & & 4 & & & & 7 & & & 8.4 \\
\hline & & \multirow[t]{4}{*}{2} & 1 & 25.2 & 23.3 & 21 & 11.2 & 3.3 & 6.4 & 9.7 \\
\hline & & & 2 & 25.5 & 24.4 & 20.7 & 10.7 & & 5.3 & 10.6 \\
\hline & & & 3 & & & & 7 & & & 9 \\
\hline & & & 4 & & & & 7 & & & 8.4 \\
\hline & \multirow[t]{6}{*}{$60 \mathrm{~g} / 1$} & \multirow[t]{2}{*}{1} & 1 & 24 & 23.7 & 20.4 & 10.2 & 6.2 & 6.2 & 10.5 \\
\hline & & & 2 & 24.4 & & & & & 4.5 & \\
\hline & & \multirow[t]{4}{*}{2} & 1 & 24 & 23.4 & 20 & 10.9 & 3.5 & 6 & 10.3 \\
\hline & & & 2 & 23 & 22.5 & 19.2 & 10.4 & & 4.5 & 10.2 \\
\hline & & & 3 & & & & 10.6 & & & 10.2 \\
\hline & & & 4 & & & & 9.2 & & & 9 \\
\hline & \multirow[t]{5}{*}{$80 \mathrm{~g} / 1$} & \multirow[t]{3}{*}{1} & 1 & 23.6 & 22.9 & 20 & 8.9 & 5.1 & 5.7 & 9.6 \\
\hline & & & 2 & 23.5 & 22 & 19.4 & 8.2 & 5 & 5.6 & 9.6 \\
\hline & & & 3 & 23.1 & 22 & 20.1 & 8.1 & 4.6 & 6.5 & 9.4 \\
\hline & & \multirow[t]{2}{*}{2} & 1 & 24.9 & 24 & 21.4 & 10.9 & 5.2 & 5.7 & 10.5 \\
\hline & & & 2 & 21.4 & 20.7 & 20 & 10.5 & 5.3 & 4.9 & 10.4 \\
\hline
\end{tabular}

$F L$ foot length, $F W$ foot width, $I$ individual, $S L$ sediment load

\section{Topography}

\section{Original Experimental Footprints}

The original experimental footprints made in the second surface are deeper than those made in the raw clay.

For the footprints made in raw clay, raised rims are observed around the margins of the digits, between the digits and the forefoot and sometime in the proximal part of the heel (Fig. 4.5a, b, c).

For the footprints made in the second surface, prominent raised rims associated with sediment displacement around their margins are more common (Fig. 4.6a, b, c). 
These pronounced raised rims and the lack of cohesion of this substrate sometimes led to the detachment of sediment plates (Fig. 4.6a, b, c).

\section{Footprint Evolution}

Following flooding, the topography of the footprints was affected. The M3C2 algorithm allowed us to compare the surface changes of a single track between two steps. This analysis reveals that footprints are filled up by clay deposits whose thickness depends on the prints and the surface area of the prints (Figs. $4.5 \mathrm{~g}$ and $4.6 \mathrm{~g})$.

For the footprints made in the first surface, the deposits that formed on the surface never exceed $10 \mathrm{~mm}$ after the last flooding (Fig. $4.5 \mathrm{~g}$ ).

For the footprints made in the second surface, the infilling is more complex (Fig. 4.6g). In addition to clay deposits, footprints are often filled up by detached sediment plates; infillings can then reach $20 \mathrm{~mm}$.

In both surfaces, the majority of the areas affected by the infillings are most often the deepest, such as the forefoot, the digits and the heel. The relief of the margins of the prints tends to decrease. Raised rims were flattened out and sediment plates eroded (Figs. 4.5g and 4.6g).

All footprints lose definition after flooding episodes, and their margins are less easily identifiable. In general, impressions made in the second surface appear to be more markedly altered than those made in the raw clay (Fig. 4.6d, e, f, g).

\section{Discussion}

Our experiments demonstrate that low-power floods do not modify the general morphology of the prints, regardless of the formation sediment and the sediment load used. However, as highlighted by the M3C2 algorithm, their topography is altered by the clay deposits and a reduction in the relief of their margins. Some detached plates resulting from the erosion of raised rims may also fill up the footprints, particularly those made in the second surface. This detachment and displacement of sediment is likely caused by the lack of cohesion of the substrate due to its high moisture content: the higher the moisture content of the sediment, the less cohesive it is. It may also be due to the lack of cohesion between the two levels of the second surface. These characteristics make the surface more fragile, and the track may be modified during flooding. Therefore, flooding episodes contribute to the loss of track definition, and the forefoot and digits are generally the most persistent areas.

These experiments also highlight that the use of biometric data on footprints to infer biological characteristics such as sex, age, stature or body mass remains an uncertain exercise. The lack of track definition and the taphonomical processes can lead to measurement errors of several centimetres. These results are consistent with 
previous taphonomic studies carried out on tracks found in open-air settings (Wiseman and De Groote 2018; Zimmer et al. 2018). Based on the Holocene site of Formby Point (North West England) for the former and the Pleistocene site Engare Sero (Tanzania) for the latter, they perfectly illustrate and quantify the erosional processes that occur immediately after track exposure. Both conclude that erosionrelated changes to tracks influence biological inferences. Previous studies have also demonstrated the uniqueness of tracks and the crucial role of the substrate in which they were formed (Pales 1976; Marty et al. 2009; Morse et al. 2013; Bennett and Morse 2014). Furthermore, it is known that a single trackmaker could produce a range of footprints with various morphologies according to the sediment on which they were formed (Morse et al. 2013; Bennett and Morse 2014). It has also been demonstrated that footprints are almost systematically larger than the feet that made them (Pales 1976; Hatala et al. 2018). Additionally, most inferences are based on modern reference populations. Regarding fossil tracks, there is no guarantee that the reference population used is representative of past variability (Bennett and Morse 2014). Although inferences made on tracks should be used with caution, they provide some insights for interpretation purposes. Experiments are therefore a useful tool to approximate the original shape of a track as closely as possible and/or to understand its alterations (Bennett and Morse 2014; Falkingham et al. 2018).

This work, based on observations made on the footprints found in Cussac Cave, provides some insights into the taphonomical effects of flooding events on the morphology and topography of footprints. Experiments based on taphonomical phenomena are still limited and mainly concern tracks found in open-air settings (Marty et al. 2009; Scott et al. 2010; Morse et al. 2013; Bennett and Morse 2014; Roach et al. 2016; Wiseman and De Groote 2018). The major difference between tracks found in open-air settings and those found in caves is probably the speed of taphonomical processes affecting them. Studies of tracks found in open-air settings have shown that a multitude of taphonomical processes (weather condition, bioturbation, properties of the sediment, etc.) preceded the burial and the diagenesis of the tracks. Consequently, their morphology was rapidly altered (Marty et al. 2009; Scott et al. 2010; Bennett et al. 2013; Wiseman and De Groote 2018; Zimmer et al. 2018). Additionally, their exposure led to degradations (Wiseman and De Groote 2018; Zimmer et al. 2018). Conversely, caves are stable environments allowing a high degree of track preservation. While tracks found in caves may be altered, it is assumed that they are disturbed less than those found in open-air settings. However, our work has demonstrated that although the damage to the footprint does not substantially alter its general morphology, its loss of definition or the destruction of certain parts can lead to unreliable interpretation.

Our analysis was based on 3D data. These techniques have become crucial in the study of ornated caves and are now replacing casts and other recording methods. They are most often used for conservation purposes and to encourage ex situ studies. They are also essential as they provide a precise picture of human and animal use of caves (Ortega Martinez et al. 2014; Pastoors et al. 2017; Citton et al. 2017; Ledoux 2019; Romano et al. 2019). Here we used the M3C2 algorithm (Lague et al. 2013) in order to quantify the surface changes to single footprints between each step. The 
same algorithm was used to quantify the ongoing erosion of the Engare Sero tracks (Zimmer et al. 2018). So far, most of the tools developed in ichnological studies have been based on the biomechanics of hominin locomotion. Consequently, these studies are more focused on the nature of the formation substrate and its interaction with the foot (Crompton et al. 2012; Morse et al. 2013; Hatala et al. 2018). While some tools such as pedobarographic statistical parametric mapping (pSPM), based on the comparison of pressure at the substrate-foot interface and footprint depth (Pataky et al. 2008a; Crompton et al. 2012; Morse et al. 2013) or biplanar X-rays studying the $3 \mathrm{D}$ dynamics at the foot-substrate interface, have focused on the formation of tracks to infer foot anatomy or biomechanics data (Hatala et al. 2018), the M3C2 algorithm focused on the evolution of these tracks over time. The application of such methods is then useful to complement qualitative observations and can help to understand certain taphonomical processes such as erosion or sedimentation.

While the experiment presented here provides promising data on the impact of clay deposits on the morphometry of a footprint, our sample was limited, and we only explored and controlled a few parameters. Additionally, these parameters do not necessarily extend to all caves and all tracks. The future integration of a larger sample of tracks produced by a larger number of trackmakers, in a variety of sediments combined with varied sediment loads contained in the flooding water, will undoubtedly further substantiate our results. This would also allow researchers to create reference tracks for each possible setting that could be used to study the tracks of different sites. Many phenomena and their influence on the morphology and biometry of tracks found in karst settings have yet to be documented: these experiments are the first step in the development of more experimental work. The creation of artificial flooding on the very limited surface of the box does not accurately reflect the reality of the overflow of a subterranean river. It would therefore be appropriate to carry out experiments directly in karst settings. One of the advantages of laboratory experiments is that they make it possible to recreate taphonomical phenomena in a very short time. However, the more complex the phenomenon, the more difficult it will be to control. Although this requires much more time, it would therefore be better to follow the evolution of tracks in real conditions and also taking the geometry of the cave into consideration.

Our results demonstrate that flooding and subsequent clay deposits in some areas of Cussac contributed to the lack of visibility of tracks. However, they do not explain the lack of details in Cussac's tracks. Only one complete footprint could be interpreted as undoubtedly human in the submerged areas (Fig. 4.1a). Although its outline is clearly visible with all the foot areas represented (forefoot, longitudinal arch and heel), no detail is apparent. These experiments show that clay deposits did not radically modify the morphology of the footprints and allowed the preservation of certain details such as digits, regardless of the formation sediment and the sediment load used. Additionally, the existence of low-power floods has been proven at Cussac. Apart from the clay deposits and some desiccation cracks, the floor does not seem to have suffered any other alteration. In our experiments, what seems to have had the most significant impact is the lack of cohesion of the second surface due to its high moisture content and its level of clay resulting from settling, causing the 
raising and displacement of sediment plates on the surface during water infiltration. However, this phenomenon did not occur at Cussac. The next step will therefore be to understand this lack of detail. Is it due to flooding or another taphonomical phenomenon? In addition to flooding, the areas involved were intensively trampled by bears, so discrimination between the two species is a challenge. By continuing our experiments, we hope to improve the determination of the prints present in these problematic areas.

\section{Conclusion}

As very few experimental works have been carried out in caves, this study will emerge as original in this type of setting. It brings new data on the taphonomy of tracks when they are subjected to flooding. Although flooding does not modify the general morphology of the tracks, their topography is altered by successive episodes and clay deposits. However, the loss of track definition and the taphonomical processes can lead to unreliable interpretation and measurement errors of several centimetres. Inferences on fossil tracks should therefore be made with caution. Our experiments were based on taphonomical phenomena observed in Cussac Cave. Although we do not yet have all the means to reliably interpret the tracks of Cussac, a larger sample involving more parameters and in situ experiments will undoubtedly allow us to refine our results and apply them to other caves.

Tracks are a significant testimony of the frequentation of caves by Palaeolithic people and their ability to adapt to an unsuitable or even dangerous environment. It is therefore essential to understand their history if we want to reconstruct past human behaviour and activities in caves and in Palaeolithic societies.

Acknowledgements We are grateful to the editors for allowing us to contribute to this chapter of this book. Our work is supported by the Projet Collectif de Recherche Cussac, and we thank all the members of its team. We are also grateful to the French Ministry of Culture and to the LaScArBx, a research programme supported by the ANR (ANR-10-LABX-52). We are also grateful to the University of Bordeaux, the PACEA laboratory and the Pôle mixte de recherche archéologique de Campagne. We also thank Mathieu Bosq for his contribution to the experiments and Christophe Mallet for his help and advice.

\section{References}

Altamura, F., Bennett, M. R., D’Août, K., Gaudzinski-Windheuser, S., Melis, R. T., Reynolds, S. C., \& Mussi, M. (2018). Archaeology and ichnology at Gombore II-2, Melka Kunture, Ethiopia: Everyday life of a mixed-age hominin group 700,000 years ago. Scientific Reports, 8, 2815. https://doi.org/10.1038/s41598-018-21158-7.

Ambert, P., Colomer, A., \& Galant, P. (2000). Datations mésolithiques des empreintes humaines de l'étage Cathala de la grotte d'Aldène (Cesseras, Hérault). Comptes Rendus de l'Académie des 
Sciences - Series IIA - Earth and Planetary Science, 331, 67-74. https://doi.org/10.1016/ S1251-8050(00)01380-X.

Ambert, P., Galant, P., \& Colomer, A. (2001). Incursions spéléologiques mésolithiques dans la grotte d'Aldène (Cesseras, Hérault). Bulletin de la Société préhistorique française, 98, 497-503. https://doi.org/10.3406/bspf.2001.12535.

Aramayo, S. A. (2009). A brief sketch of the Monte Hermoso human footprint site, South Coast of Buenos Aires Province, Argentina. Ichnos, 16, 49-54. https://doi.org/10.1080/ 10420940802470748.

Arias, P., Laval., E., Menu, M., Sainz, C.G., Ontañon, R. (2011). Les colorants dans l'art pariétal et mobilier paléolithique de la Garma (Cantanbrie, Espagne). L'Anthropologie, 115(3-4), 425-445.

Ashton, N., Lewis, S. G., De Groote, I., Duffy, S. M., Bates, M., Bates, R., Hoare, P., Lewis, M., Parfitt, S. A., Peglar, S., Williams, C., \& Stringer, C. (2014). Hominin footprints from early Pleistocene deposits at Happisburgh, UK. PLOS ONE, 9. https://doi.org/10.1371/journal.pone. 0088329.

Aujoulat, N., Geneste, J.-M., Archambeau, C., Delluc, M., Duday, H., \& Gambier, D. (2001). La grotte ornée de Cussac (Dordogne). Observations préliminaires. PALEO Revue d'archéologie préhistorique, 13, 9-18.

Aujoulat, N., Geneste, J.-M., Archambeau, C., Delluc, M., Duday, H., \& Henry-Gambier, D. (2002). La grotte ornée de Cussac - Le Buisson-de-Cadouin (Dordogne) : premières observations. Bulletin de la Société préhistorique française, 99, 129-137. https://doi.org/10. 3406/bspf.2002.12612.

Aujoulat, N., Feruglio, V., Fourment, N., Henry-Gambier, D., \& Jaubert, J. (2013). Le sanctuaire gravettien de Cussac (Le Buisson-de-Cadouin, Dordogne, France) : premiers résultats d'un projet collectif de recherche. International Newsletter on Rock Art (INORA), 65, 7-19.

Bégouën, R., Fritz, C., Tosello, G., Clottes, J., Pastoors, A., \& Faist, F. (2009). Le Sanctuaire secret des bisons. Il y a 14000 ans, dans la caverne du Tuc d'Audoubert. Paris: Editons d'art Somogy Association Louis Bégouën.

Bennett, M. R., \& Morse, S. A. (2014). Human footprints: Fossilised locomotion? Cham: Springer International Publishing.

Bennett, M. R., Harris, J. W. K., Richmond, B. G., Braun, D. R., Mbua, E., Kiura, P., Olago, D., Kibunjia, M., Omuombo, C., Behrensmeyer, A. K., Huddart, D., \& Gonzalez, S. (2009). Early hominin foot morphology based on 1.5-million-year-old footprints from Ileret, Kenya. Science, 323, 1197-1201. https://doi.org/10.1126/science.1168132.

Bennett, M. R., Falkingham, P., Morse, S. A., Bates, K., \& Crompton, R. H. (2013). Preserving the impossible: Conservation of soft-sediment hominin footprint sites and strategies for threedimensional digital data capture. PLoS One, 8, e60755. https://doi.org/10.1371/journal.pone. 0060755.

Bennett, M. R., Reynolds, S. C., Morse, S. A., \& Budka, M. (2016). Laetoli's lost tracks: 3D generated mean shape and missing footprints. Scientific Reports, 6, 21916.

Berge, C., Penin, X., \& Pellé, É. (2006). New interpretation of Laetoli footprints using an experimental approach and Procrustes analysis: Preliminary results. Comptes Rendus Palevol, 5, 561-569. https://doi.org/10.1016/j.crpv.2005.09.001.

Brand, L. R. (1996). Variations in salamander trackways resulting from substrate differences. Journal of Paleontology, 70, 1004-1010. https://doi.org/10.1017/S0022336000038701.

Burns, A. (2014). The prehistoric footprints at Formby: Discover the footprints on the Sefton coast and take a glimpse into prehistoric Britain. Ainsdale: Sefton Coast Landscape Partnership Scheme.

Citton, P., Romano, M., Salvador, I., \& Avanzini, M. (2017). Reviewing the upper Pleistocene human footprints from the 'Sala dei Misteri' in the Grotta della Bàsura (Toirano, northern Italy) cave: An integrated morphometric and morpho-classificatory approach. Quaternary Science Reviews, 169, 50-64. https://doi.org/10.1016/j.quascirev.2017.05.016. 
Clottes, J., \& Simonnet, R. (1972). Le réseau René Clastres de la caverne de Niaux (Ariège). Bulletin de la Société préhistorique française Études et travaux, 69(1), 293-323.

Crompton, R. H., Pataky, T. C., Savage, R., D’Août, K., Bennett, M. R., Day, M. H., Bates, K., Morse, S., \& Sellers, W. I. (2012). Human-like external function of the foot, and fully upright gait, confirmed in the 3.66 million year old Laetoli hominin footprints by topographic statistics, experimental footprint-formation and computer simulation. Journal of the Royal Society Interface, 9, 707-719. https://doi.org/10.1098/rsif.2011.0258.

D’Août, K., Meert, L., Van Gheluwe, B., De Clercq, D., \& Aerts, P. (2010). Experimentally generated footprints in sand: Analysis and consequences for the interpretation of fossil and forensic footprints. American Journal of Physical Anthropology, 141, 515-525. https://doi.org/ 10.1002/ajpa.21169.

Duday, H., \& Garcia, M. A. (1983). Les empreintes de l'Homme préhistorique. La grotte du PechMerle à Cabrerets (Lot): une relecture significative des traces de pieds humains. Bulletin de la Société préhistorique française, 80(7), 208-215.

Duday, H., \& Garcia, M. A. (1985). L'homme et la caverne. Dossiers d'Archéologie, 90, 35-39.

Duday, H., \& Garcia, M. A. (1986). La Paléo Ichnologie humaine (étude des empreintes fossiles). Bulletin de la Société d'Anthropologie du Sud-Ouest Bordeaux, 21, 1.

Falkingham, P. L., Bates, K. T., Avanzini, M., Bennett, M., Bordy, E. M., Breithaupt, B. H., Castanera, D., Citton, P., Díaz-Martínez, I., Farlow, J. O., Fiorillo, A. R., Gatesy, S. M., Getty, P., Hatala, K. G., Hornung, J. J., Hyatt, J. A., Klein, H., Lallensack, J. N., Martin, A. J., Marty, D., Matthews, N. A., Meyer, C. A., Milàn, J., Minter, N. J., Razzolini, N. L., Romilio, A., Salisbury, S. W., Sciscio, L., Tanaka, I., Wiseman, A. L. A., Xing, L. D., \& Belvedere, M. (2018). A standard protocol for documenting modern and fossil ichnological data. Palaeontology, 61, 469-480. https://doi.org/10.1111/pala.12373.

Felstead, N. J., Gonzalez, S., Huddart, D., Noble, S. R., Hoffmann, D. L., Metcalfe, S. E., Leng, M. J., Albert, B. M., Pike, A. W. G., Gonzalez-Gonzalez, A., \& Jiménez-López, J. C. (2014). Holocene-aged human footprints from the Cuatrociénegas Basin, NE Mexico. Journal of Archaeological Science, 42, 250-259. https://doi.org/10.1016/j.jas.2013.11.010.

Fourment, N., Baraud, D., Kazmierczak, M., \& Rieu, A. (2012). La grotte de Cussac (Le Buissonde-Cadouin, Dordogne, France): Applications des principes de conservation préventive au cas d'une découverte récente. In J. Clottes (Ed.), L'art pléistocène dans le monde/Pleistocene artof the worls/Arte pleistoceno en el mundo. Actes du Congrès IFRAO, Tarascon-sur-Ariège, septembre 2010 (pp. 343-354). Tarascon-sur-Ariège: Société Préhistorique Ariège-Pyrénées.

Garcia, M. A. (1986). Pour une bibliographie des empreintes humaines et animales. Paris: Publications scientifiques du Muséum national d'Histoire naturelle.

Garcia, M. A. (2001). Les empreintes et les traces humaines et animales. In J. Clottes (Ed.), $L a$ grotte Chauvet. L'art des origines (pp. 34-43). Paris: Éditions du Seuil.

Garcia, M. A. Ichnologie générale de la grotte Chauvet. Bulletin de la Société préhistorique française, 102, 103-108. https://doi.org/10.3406/bspf.2005.13341.

Garcia, M. A., \& Duday, H. (1983). Grotte de Foissac (Aveyron) A propos d'une découverte récente ou de l'ichnologie comme mode d'approche des structures préhistoriques en grotte. Bulletin de la Société préhistorique française, 80, 184-187. https://doi.org/10.3406/bspf.1983. 5441.

Garcia, M. A., Duday, H., \& Courtaud, P. (1990). Les empreintes du Réseau Clastres. Préhistoire Ariégeoise, 45, 167-174.

Gatesy, S. (2003). Direct and indirect track features: What sediment did a dinosaur touch? Ichnos, 10, 91-98. https://doi.org/10.1080/10420940390255484.

Hatala, K. G., Perry, D. A., \& Gatesy, S. M. (2018). A biplanar X-ray approach for studying the 3D dynamics of human track formation. Journal of Human Evolution, 121, 104-118. https://doi. org/10.1016/j.jhevol.2018.03.006.

Hatala, K. G., Dingwall, H. L., \& Wunderlich, R. E. Richmond, B.G. (2013) the relationship between plantar pressure and footprint shape. Journal of Human Evolution, 65, 21-28. https:// doi.org/10.1016/j.jhevol.2013.03.009. 
Henry-Gambier, D., Courtaud, P., Dutailly, B., Villotte, S., Deguilloux, M. F., Pemonge, M. H., Aujoulat, N., Delluc, M., Fourment, N., \& Jaubert, J. (2013). Grotte de Cussac (Le Buisson-deCadouin, Dordogne): un exemple de comportement original pour le Gravettien. In J. Jaubert, N. Fourment, \& P. Depaepe (Eds.), Transitions, ruptures et continuité en Préhistoire, Actes du XXVIIe congrès préhistorique de France, Bordeaux-Les Eyzies 31 mai-5 juin 2010 (pp. 169-182). Paris: Société Préhistorique Française.

Jaubert, J. (2015). Une invitation à Jiří Svoboda pour jumeler le complexe pavlovien de Moravie et la grotte ornée et funéraire d’âge Gravettien de Cussac. In S. Sázelová, M. Novák, \& A. Mizerová (Eds.), Forgotten times and spaces: New perspectives in paleoanthropological, paleoetnological and archeological studies (pp. 214-228). Brno: Masaryk university.

Jaubert, J., Aujoulat, N., Courtaud, P., Deguilloux, M. F., Delluc, M., Denis, A., Duday, H., Dutailly, B., Ferrier, C., Feruglio, V., Fourment, N., Geneste, J.-M., Genty, D., Goutas, N., Henry-Gambier, D., Kervazo, B., Klaric, L., Lastennet, R., Levêque, F., Malaurent, P., Mallye, J.-B., Mora, P., Pemonge, M. H., Peyraube, N., Peyroux, M., Plisson, H., Portais, J.-C., Valladas, H., Vergnieux, R., \& Villotte, S. (2012). Le projet collectif de recherche "Grotte de Cussac" (Dordogne, France): étude d'une cavité ornée à vestiges humains du Gravettien. In J. Clottes (Ed.), L'art pléistocène dans le monde/Pleistocene artof the worls/Arte pleistoceno en el mundo. Actes du Congrés IFRAO, septembre 2010 (pp. 325-342). Tarascon-sur Ariège: Société Préhistorique Ariège-Pyrénées.

Jaubert, J., Genty, D., Valladas, H., Camus, H., Courtaud, P., Ferrier, C., Feruglio, V., Fourment, N., Konik, S., Villotte, S., Bourdier, C., Costamagno, S., Delluc, M., Goutas, N., Katnecker, É., Klaric, L., Langlais, M., Ledoux, L., Maksud, F., O’Farrell, M., Mallye, J.-B., Pierre, M., PonsBranchu, E., Régnier, É., \& Théry-Parisot, I. (2017). The chronology of human and animal presence in the decorated and sepulchral cave of Cussac (France). Quaternary International, 432, 5-424. https://doi.org/10.1016/j.quaint.2016.01.052.

Lague, D., Brodu, N., \& Leroux, J. (2013). Accurate 3D comparison of complex topography with terrestrial laser scanner: Application to the Rangitikei canyon (N-Z). ISPRS Journal of Photogrammetry and Remote Sensing, 82, 10-26. https://doi.org/10.1016/j.isprsjprs.2013.04.009.

Ledoux, L. (2019). L'ichnologie préhistorique et les traces d'activités au sein des cavités ornées. Les grottes de Fontanet (Ariège) et de Cussac (Dordogne). PhD thesis, Université de Bordeaux, France.

Ledoux, L., Fourment, N., Maksud, F., Delluc, M., Costamagno, S., Goutas, N., Klaric, L., Laroulandie, V., Salomon, H., \& Jaubert, J. (2017). Traces of human and animal activity (TrAcs) in Cussac Cave (Le Buisson-de-Cadouin, Dordogne, France): Preliminary results and perspectives. Quaternary International, 430, 141-154. https://doi.org/10.1016/j.quaint.2016. 06.002 .

Marty, D., Strasser, A., \& Meyer, C. A. (2009). Formation and taphonomy of human footprints in microbial mats of present-day tidal-flat environments: Implications for the study of fossil footprints. Ichnos, 16, 127-142. https://doi.org/10.1080/10420940802471027.

Masao, F. T., Ichumbaki, E. B., Cherin, M., Barili, A., Boschian, G., Iurino, D. A., Menconero, S., Moggi-Cecchi, J., \& Manzi, G. (2016). New footprints from Laetoli (Tanzania) provide evidence for marked body size variation in early hominins. eLife, 5. https://doi.org/10.7554/ eLife. 19568.

McLaren, D., Fedje, D., Dyck, A., Mackie, Q., Gauvreau, A., \& Cohen, J. (2018). Terminal Pleistocene epoch human footprints from the Pacific coast of Canada. PLoS One, 13, e0193522. https://doi.org/10.1371/journal.pone.0193522.

Medina-Alcaide, M. Á., Garate-Maidagan, D., Ruiz-Redondo, A., \& Sanchidrián-Torti, J. L. (2018). Beyond art: The internal archaeological context in Paleolithic decorated caves. Journal of Anthropological Archaeology, 49, 114-128. https://doi.org/10.1016/j.jaa.2017.12.005.

Mietto, P., Avanzini, M., \& Rolandi, G. (2003). Palaeontology: Human footprints in Pleistocene volcanic ash. Nature, 422, 133-133. 
Milàn, J., \& Bromley, R. G. (2007). The impact of sediment consistency on track and undertrack morphology: Experiments with emu tracks in layered cement. Ichnos, 15, 19-27. https://doi.org/ 10.1080/10420940600864712.

Modabber, A., Peters, F., Kniha, K., Goloborodko, E., Ghassemi, A., Lethaus, B., Hölzle, F., \& Möhlhenrich, S. C. (2016). Evaluation of the accuracy of a mobile and a stationary system for three-dimensional facial scanning. Journal of Cranio-Maxillofacial Surgery, 44, 1719-1724.

Moreno, K., Bostelmann, J. E., Macías, C., Navarro-Harris, X., Pol-Holz, R. D., \& Pino, M. (2019). A late Pleistocene human footprint from the Pilauco archaeological site, northern Patagonia, Chile. PLoS One, 14, e0213572. https://doi.org/10.1371/journal.pone.0213572.

Morse, S. A., Bennett, M. R., Liutkus-Pierce, C., Thackeray, F., McClymont, J., Savage, R., \& Crompton, R. H. (2013). Holocene footprints in Namibia: The influence of substrate on footprint variability: Holocene footprints in Namibia. American Journal of Physical Anthropology, 151, 265-279. https://doi.org/10.1002/ajpa.22276.

Ortega Martinez, A. I., Ruiz García, F., Benito Calvo, A., Martín Merino, M. A., Karampaglidis, T., \& Campaña Lozano, I. (2014). Escaneado en 3D de las Galerías de las Huellas (Ojo Guareña, Merindad de Sotoscueva, Burgos). Cubía Boletin, 18, 38-47.

Pales, L. (1976). Les Empreintes de pieds humains dans les cavernes. In Les empreintes du réseau nord de la caverne de Niaux (Ariège). Paris et al.: Masson.

Panerello, A., Santello, L., Farinaro, G., Bennett, M. R., \& Mietto, P. (2017). Walking along the oldest human fossil pathway (Roccamonfina volcano, Central Italy)? Journal of Archaeological Science: Reports, 13, 476-490. https://doi.org/10.1016/j.jasrep.2017.04.020.

Pastoors, A., \& Weniger, G.-C. (2011). Cave art in context: Methods for the analysis of the spatial organization of Cave Sites. Journal of Archaeological Research, 19, 377-400.

Pastoors, A., Lenssen-Erz, T., Ciqae, T., Kxunta, U., Thao, T., Bégouën, R., Biesele, M., \& Clottes, J. (2015). Tracking in caves: Experience based reading of pleistocene human footprints in French caves. Cambridge Archaeological Journal, 25, 551-564. https://doi.org/10.1017/ S0959774315000050.

Pastoors, A., Lenssen-Erz, T., Breuckmann, B., Ciqae, T., Kxunta, U., Rieke-Zapp, D., \& Thao, T. (2017). Experience based reading of Pleistocene human footprints in Pech-Merle. Quaternary International, 430, 155-162. https://doi.org/10.1016/j.quaint.2016.02.056.

Pataky, T. C., \& Goulermas, J. Y. (2008). Pedobarographic statistical parametric mapping (pSPM): A pixel-level approach to foot pressure image analysis. Journal of Biomechanics, 41, 2136-2143. https://doi.org/10.1016/j.jbiomech.2008.04.034.

Pataky, T. C., Caravaggi, P., Savage, R., Parker, D., Goulermas, J. Y., Sellers, W. I., \& Crompton, R. H. (2008a). New insights into the plantar pressure correlates of walking speed using pedobarographic statistical parametric mapping (pSPM). Journal of Biomechanics, 41, 1987-1994. https://doi.org/10.1016/j.jbiomech.2008.03.034.

Pataky, T. C., Goulermas, J. Y., \& Crompton, R. H. (2008b). A comparison of seven methods of within-subjects rigid-body pedobarographic image registration. Journal of Biomechanics, 41, 3085-3089. https://doi.org/10.1016/j.jbiomech.2008.08.001.

Raichlen, D. A., Gordon, A. D., Harcourt-Smith, W. E. H., Foster, A. D., \& Haas, W. M. R. (2010). Laetoli footprints preserve earliest direct evidence of human-like bipedal biomechanics. PLoS One, 5, e9769. https://doi.org/10.1371/journal.pone.0009769.

Roach, N. T., Hatala, K. G., Ostrofsky, K. R., Villmoare, B., Reeves, J. S., Du, A., Braun, D. R., Harris, J. W. K., Behrensmeyer, A. K., \& Richmond, B. G. (2016). Pleistocene footprints show intensive use of lake margin habitats by Homo erectus groups. Scientific Reports, 6, 26374. https://doi.org/10.1038/srep26374.

Romano, M., Citton, P., Salvador, I., Arobba, D., Rellini, I., Firpo, M., Negrino, F., Zunino, M., Starnini, E., \& Avanzini, M. (2019). A multidisciplinary approach to a unique Palaeolithic human ichnological record from Italy (Bàsura Cave). bioRxiv, 529404. https://doi.org/10.1101/ 529404. 
Scott, J. J., Renaut, R. W., \& Owen, R. B. (2010). Taphonomic controls on animal tracks at saline, alkaline Lake Bogoria, Kenya Rift Valley: Impact of salt efflorescence and clay mineralogy. Journal of Sedimentary Research, 80, 639-665. https://doi.org/10.2110/jsr.2010.057.

Smith, G. M., Parsons, T., Harrod, R. P., Holmes, C. E., Reuther, J. D., \& Potter, B. A. (2019). A track in the Tanana: Forensic analysis of a late Holocene footprint from Central Alaska. Journal of Archaeological Science: Reports, 24, 900-912. https://doi.org/10.1016/j.jasrep.2019.03.016.

Sollas, W. J. (1879). On some three-toed footprints from the Triassic conglomerate of South Wales. Quarterly Journal of the Geological Society, 35, 511-515. https://doi.org/10.1144/GSL.JGS. 1879.035.01-04.33.

Webb, S., Cupper, M. L., \& Robins, R. (2006). Pleistocene human footprints from the Willandra Lakes, southeastern Australia. Journal of Human Evolution, 50, 405-413. https://doi.org/10. 1016/j.jhevol.2005.10.002.

Wiseman, A. L. A., \& De Groote, I. (2018). A three-dimensional geometric morphometric study of the effects of erosion on the morphologies of modern and prehistoric footprints. Journal of Archaeological Science: Reports, 17, 93-102. https://doi.org/10.1016/j.jasrep.2017.10.044.

Zimmer, B., Liutkus-Pierce, C., Marshall, S. T., Hatala, K. G., Metallo, A., \& Rossi, V. (2018). Using differential structure-from-motion photogrammetry to quantify erosion at the Engare Sero footprint site, Tanzania. Quaternary Science Reviews, 198, 226-241. https://doi.org/10.1016/j. quascirev.2018.07.006.

Open Access This chapter is licensed under the terms of the Creative Commons Attribution 4.0 International License (http://creativecommons.org/licenses/by/4.0/), which permits use, sharing, adaptation, distribution and reproduction in any medium or format, as long as you give appropriate credit to the original author(s) and the source, provide a link to the Creative Commons license and indicate if changes were made.

The images or other third party material in this chapter are included in the chapter's Creative Commons license, unless indicated otherwise in a credit line to the material. If material is not included in the chapter's Creative Commons license and your intended use is not permitted by statutory regulation or exceeds the permitted use, you will need to obtain permission directly from the copyright holder. 